\title{
Shaping entrepreneurial citizens: A genealogy of entrepreneurship education in Sweden
}

\author{
Magnus Dahlstedt and Andreas Fejes \\ Journal Article
}

\section{Tweet}

N.B.: When citing this work, cite the original article.

This is a postprint version of an article published in:

Magnus Dahlstedt and Andreas Fejes, Shaping entrepreneurial citizens: A genealogy of entrepreneurship education in Sweden, Critical Studies in Education, 2017.

Critical Studies in Education is available online at informaworldTM:

http://dx.doi.org/10.1080/17508487.2017.1303525

Copyright: Taylor \& Francis (Routledge): SSH Titles

http://www.routledge.com/

Postprint available at: Linköping University Electronic Press

http://urn.kb.se/resolve?urn=urn:nbn:se:liu:diva-136471 


\title{
Shaping entrepreneurial citizens: A genealogy of entrepreneurship education in Sweden
}

\author{
Magnus Dahlstedt \& Andreas Fejes (magnus.dahlstedt@liu.se; andreas.fejes@liu.se) \\ Linköping University
}

\section{Full reference:}

Dahlstedt, M \& Fejes, A. (2017) Shaping entrepreneurial citizens: A genealogy of entrepreneurship education in Sweden. Critical Studies in Education.

doi:10.1080/17508487.2017.1303525

\begin{abstract}
The focus of this article is the discourse of entrepreneurship education in Sweden. Drawing on a genealogical approach, the analysis draws attention to how this discourse is shaped in the curriculum today, and how it has come to emerge. Focusing on two key events that constitute this discourse, responsibility and problem-solving, and tracing these events back in time, the analysis illustrates how the discourse on entrepreneurship education today shapes a specific kind of citizen, one who is responsible for themselves and who has developed a constant will and desire for learning, thus being able to adapt to the constant changing future. Such a citizen is distinctly different from the one emerging in the 1960s and 1980s, where a citizen that shows solidarity with others, and especially the weak, and who develops problem- solving skills in order to actively engage in the development of society, emerges. These results can be related to wider trends in education policy, where neoliberal rationalities have become more central, in Sweden as well as in other countries, where there has been a shift of focus, from an understanding of education as a common good, to an understanding of education as a private good.
\end{abstract}

\section{Introduction}

The focus of this article is the growing importance of entrepreneurship in the context of Swedish education policy, as part of an international trend in education policy more broadly (Peters, 2001; Mahieu, 2006). In recent decades, entrepreneurship has been emphasized as crucial for each country when it comes to succeeding in the competition in the globalized 'knowledge-based society' of today - not least in the European Union (Bengtsson, 2014). For instance, since 2006, a sense of initiative and entrepreneurship has been promoted as one of the 'key competences' for lifelong learning identified by the EU, and entrepreneurship education has come to the fore as a way to promote such competencies (European Union, 2006).

Sweden has also seen this increasing interest in entrepreneurship education. In Sweden, the concept of entrepreneurship education was introduced in the mid-1990s, highlighting the importance of education as a means of making the Swedish population more 'entrepreneurial' (Leffler, 2009; Dahlstedt \& Hertzberg, 2012). In the last two decades, the concept has become mainstream, and in 2011 it was included in the curriculum where it is stated that 'the school should help the students to develop an approach promoting entrepreneurship' (Lgr 11, 2011, p. 6). Thus, what had been a central discourse for more than a decade was now formalised as something that should permeate all teaching in schools. However, these developments in Swedish education policy and in the curriculum are part of a wider set of neoliberal welfare reforms, where there has been a gradual shift towards emphasizing, not only entrepreneurship, but also individual autonomy and responsibility, freedom of choice vis-à-vis state responsibility, and interventions to achieve equality by the redistribution of resources (Hvinden \& Johansson, 2007; Dahlstedt \& Trumberg, 2017; Lundahl et al., 2014).

In previous research there are studies focusing on the development of policy discourses of entrepreneurship education and entrepreneurial learning, as part of wider changes in education policy, in Sweden (Olson \& Dahlstedt, 2014), the EU (Hytti \& O'Gorman, 2004; Bengtsson. 2014) as well as internationally (Brunila, 2011). Other studies have focused on the ways teachers work with and interpret what entrepreneurship education is all about (Komulainen, 
et al. 2009; Holmgren, 2012; Korhonen, et al. 2012; Wallin, 2014) and how entrepreneurial discourse is internalised by students, shaping certain kinds of subjectivities (Brunila 2012). Generally, such research points out that there are both narrow and broad definitions of entrepreneurship in education. In the narrower definition, entrepreneurship education is focused on business activities, with specific teaching methods aimed at teaching students how to start a company (Mahieu, 2006). The broader definition promotes an idea that students should learn a set of 'entrepreneurial skills' such as independence, creativity, problem-solving and diligence (Berglund \& Holmgren, 2007; Leffler, 2006; Svedberg, 2007; Leffler \& Svedberg, 2005; Komulainen, et al. 2011). However, no matter which definition is used, entrepreneurship and entrepreneurship education have become key concepts, mainstream, and taken for granted as natural and important in order to solve the challenges of the future. Thus, there is a need for further critical scrutiny.

This article aims to contribute to the debates on entrepreneurship education more generally, as well as to the debates on entrepreneurship in Sweden more specifically. Drawing on a genealogical approach, our focus is on how the discourse of entrepreneurship education is shaped in the school curriculum today, and how such discourse has come to emerge.

\section{Analytical framework}

In order to destabilise current discourses on entrepreneurship education, we draw on a genealogical approach inspired by the work of Foucault $(1983,1991)$ and education scholars who have further developed such an approach (Fejes \& Dahlstedt, 2013; Popkewitz, 1998). A genealogy questions the constant search for origins and beginnings or for truths about human nature or the world; it questions the search for essence and stability. The starting point is rather to destabilise and question the taken-for-granted ways in which we think and go about doing things in the present day (Taylor, 2010). This ambition is political as the aim is to open up a space to live the present otherwise (Fejes \& Dahlstedt, 2013). This does not mean, however, that the genealogist is aiming to provide another universal truth or meta-narrative of the present; rather, the aim is to provide alternatives to the present animated by an activism of which Foucault himself spoke in relation to this work. As Foucault (1983) argues:

My point is not that everything is bad, but that everything is dangerous, which is not exactly the same as bad. If everything is dangerous, then we always have something to do. So my position leads not to apathy but to a hyper and pessimistic activism. (p. 231-232)

Tracing lines of descent and emergence means focusing on how a certain power/knowledge constellation emerges. Power in such a perspective is quite different from our everyday understanding of the concept. Usually, we say that knowledge is power, that is, we assume that power resides with a certain person who is then able to wield this power over others. We further assume that those who do not have power are easily oppressed (Foucault, 2007). This definition of power is the figure of the monarch, and it draws on an image of both power-law and powersovereign. Foucault (1998, p. 89) urged us ask a 'how' question of power, rather than 'where is power' and 'where does it come from'. Focusing on a 'how' question would help us to avoid forming a unified theory of power or avoid taking the point of departure in the idea that power pre-exists.

Power relations are immanent in all relations because they encompass both their conditions and their effects. Power makes certain actions and distinctions possible; at the same time, power is the effect of these actions and distinctions. Importantly, these relations are both intentional and non-subjective, that is, power is always exercised with an aim and objective, but this is not the result of a choice made by any individual or group, but rather of a calculated strategy that coordinates power (linking explicit tactics on the local level), that draws on support 
from elsewhere, and that forms a perfectly clear and comprehensive logic system. This is 'an implicit characteristic of the great anonymous' (Foucault, 1998, p. 95).

Conducting a genealogical analysis thus concerns a focus on the present, how the present came about through the operation of power, and thus, aims to destabilise the things we take for granted ${ }^{1}$. In this article, the genealogical approach thus, in the first step, directs its focus towards questions about how the discourse on entrepreneurship education is shaped today in the present curriculum, what problems such education is meant to solve, and what the effects of such discourse are in terms of shaping certain subjectivities. In the second step, our analysis directs attention to the question of how such discourse, power relations, and effects came to emerge. This is done by tracing the lines of descent and emergence of the discourse on entrepreneurship education, focusing on the three previous curriculums from 1969, 1980 and 1994. Do key values and ideas in the present curriculum emerge in the previous ones, and if so, how?

The analysed material consists of two kinds of sources. Firstly, we have selected the curriculum from 1969, 1980, 1994 and 2011 for further analysis, thus being able to trace back in time key ideas and values emerging in the curriculum today. Secondly, in order to provide a wider and more nuanced basis for analysing the current discourse, policy documents from the late 1990s and the 2000s that focus on, among other things, entrepreneurship education, have been selected for analysis. ${ }^{2}$

Our analysis is structured in three sections. In the first section, we mainly focus on the emergence of the discourse of entrepreneurship education in Sweden by analysing policy documents from the last 20 years, as well as the current curriculum. In the second and third section, we turn our attention to the former three curriculum texts, and our focus is directed at two key organisational events that lie behind the historical beginnings of the discourse today: responsibility and problem-solving. These two events were identified as central to the current discourse on entrepreneurship education, and thus acted as an analytical vantage point when going back to the older curricular texts.

\section{A discourse on entrepreneurship education in Sweden}

The curriculum analysed have in this article been developed in different political contexts, as part of wider changes in Swedish education policy as well as welfare policy more broadly. While the curriculum of 1969 was developed by a Social democratic government in office, the curriculums of 1980, 1994 and 2011 were all developed by centre-right governments in office, each one of them as part of the specific repertoire of definitions in terms of challenges of education as well as responses to these challenges, in these particular contexts.

In the last two decades, during which the last two of the curriculums analysed have been developed, there has been quite a dramatic transformation of Swedish education policy, where a series of market-oriented reforms have had far-reaching consequences for the Swedish education system (Lundahl, et al. 2014). In the Swedish social democratic welfare model established after WWII, the organization of the education system rested on the pillars of nonsegregation, social levelling, equality, general citizen-competence, and public responsibility for education (Rothstein, 1998). However, as a result of the market-oriented reforms initiated since the early 1990s, started earlier on but taking off with a centre-right government in office (19911994), there has been a gradual shift of focus in education policy, where education has come to be seen more as a 'private good', a springboard for the individual, rather than as a 'public good', a fundamental social right for all citizens (Englund, 1996).

In line with these changes in education policy, a range of new concepts and ways of

\footnotetext{
${ }^{1}$ A genealogical analysis focus on discourse, and how discourse make available certain ways to conceptualise the world. Thus, issues about what 'really' happens in practice are left out.

2 Throughout the article, the curriculums of 1969, 1980, 1994 and 2011 respectively are referred to as Lgr 1969, Lgr 1980, Lpo 1994, Lgr 11. All quotes from these and other documents have been translated from Swedish to English by the authors.
} 
conceptualising education and learning have been introduced in policy discourse with centre-right governments (1991-1994, 2006-2014) as well as social democratic governments (1994-2006, 2014-) in office. Here, there has been an increasing focus on the economic benefit and competitiveness of education. According to a neoliberal rationality, education has increasingly been understood in terms of investment, that is something that individuals have to invest in, in order to become competitive in an ever-changing 'knowledge-economy' (Fejes \& Dahlstedt, 2013). One of these new concepts is that of entrepreneurship (Mahieu, 2006; Leffler, 2009). Some of those arguing for far-reaching changes in the Swedish educational system now strongly emphasize the importance of developing entrepreneurship education (Johannisson, et al., 2000; Nyström, 1999).

When entrepreneurship began to emerge as central in educational discourse in Sweden, in the middle of the 1990s, the argument for introducing teaching of entrepreneurship was mainly related to the needs and demands of the labour market. The overarching goal was to make young people more willing to start their own businesses after graduation, because it was argued that this would have positive effects on the labour market, the economy, and thus Swedish society in general. For example, in the 1995 Employment Bill, put forward by the social democratic government, influencing the attitudes among young people is emphasized as one of the most important motives for the promotion of entrepreneurship in the Swedish school system suggested. Problem-solving abilities are key characteristics sought by students.

Attitudes play an important role in enterprise and entrepreneurship [...] An increased emphasis on entrepreneurship in the educational system is motivated not only by the need for a more business-friendly environment. An enterprising culture, in a broad sense, includes general skills such as creativity, initiative and flexibility. Acquiring the ability of problem-solving is designated as a central objective in the new curricula. (Prop 1995/96: 222 \522)

The same kind of argument is developed in the first governmental report on entrepreneurship in education, In the sign of entrepreneurship, from 1997. In the foreword of this report, the state secretary from the Ministry of Trade and Industry states:

Globalization and rapid technological changes are making the work organizations more flexible, which increase[s] the need [for] energetic individuals. The requirement for individual problem-solving ability, ability to take initiative, ability to be creative and flexible increases, and so does the need for self-reliance. In order to secure growth and jobs, we simply have to develop a greater element of entrepreneurship in the sense of individual enterprise in the whole society. There is a general consensus that the foundations of entrepreneurship and enterprise have to be developed in school. [...] It is essential that developing a more entrepreneurial educational system in various ways be considered a priority and that information about how entrepreneurship can be promoted is spread at various levels in the educational system. (Ds 1997: 3, p. 3).

In this quote, it is argued that fundamental transformations in the outside world make the mobilisation of entrepreneurship in education unavoidable, an argument that was a recurring theme in the discourse of entrepreneurship education that took shape in the mid-1990s. Such changes are closely connected to ideas of economic prosperity and growth. In order to meet the changing future, with all its challenges, students have to become entrepreneurial, flexible and adaptable to change.

By the turn of the millennium, the discourse on entrepreneurship education had become part of the mainstream discourse in Swedish education policy. When revising the existing 
curriculum in 2009, the centre-right government made clear that the issue of entrepreneurship was one of the main priorities. As noted in a report in 2009 about the ongoing work:

The government considers that entrepreneurship should be a theme running through the entire education system. [...] The basis for developing an entrepreneurial approach should be established early on, for example by stimulating girls' and boys' curiosity, creativity, confidence and ability to make decisions. (The Government Offices, 2009, p. 9)

Here, the entrepreneur is described as a certain kind of subject, with certain characteristics, namely 'curiosity, creativity, confidence and ability to make decisions'. The entrepreneur is here described as a learning subject of a certain kind, in a constant search for new knowledge and willing to actively treat problems as possibilities.

With the revised curriculum of 2011, the concept of entrepreneurship became part of the mainstream vocabulary in Swedish education policy, appearing in the curriculum for the first time.

An important task of the school is to give an overview and context. The school should encourage students' creativity, curiosity and self-confidence, and their willingness to test ideas and solve problems. Students should have the opportunity to take the initiative and responsibility, and develop their ability to work both independently and with others. In this way, the school should help the students to develop an approach promoting entrepreneurship. (Lgr 11, 2011, p. 6)

Here, we can see how there are regularities of description within the discourse on entrepreneurship education, where the skills that students need to develop in order to become ideal citizens and provide a basis for society to face the challenges of the future are creativity, curiosity, self-confidence, and willingness to test ideas and solve problems.

To sum up the discussion thus far: within the discourse on entrepreneurship education, the problem that is identified is the changing present, with globalization and competition on a global scale. With the increasing speed of change, and its associated economic challenges, the logic construed is that there is a need for a different and better model of education. Through entrepreneurship education, the hope is that a 'new' and different student will emerge, one who can adapt to the changing present with skills such as a willingness to test ideas and solve problems, and who has a sense of responsibility for themselves and others. These ideas thus become taken for granted, neutralised and are even seen as devoid of power, and therefore they are problematic or even dangerous and in need of further scrutiny (cf. Foucault, 1983).

In order to further scrutinize and destabilise the discourse on entrepreneurship education, we will now turn to our attention towards the way the discourse came about. Or more precisely, by turning to the curriculums from 1969, 1980, and 1994, we will trace two of the key organisational events that lie behind the historical beginnings of the discourse today, namely, responsibility - for oneself as well as for others - and problem solving, the ability as well as willingness to solve problems. These two events are by no means new in the context of Swedish education policy. Quite the contrary, they have been at the very centre of education discourse for a long time, even though they have been given quite different meanings at different times in history.

\section{Responsibility - for the self and others}

In the current curriculum of 2011, entrepreneurship education is connected to an idea of responsibility, for the self and for others. Such responsibility concerns the 'ability to work both independently and with others' (Lgr 11, 2011, p. 6). The focus is thus on work, and abilities connected to cooperation, but also concerns the ability to be self-sufficient. Such a focus is also 
distinct in the curriculum from 1969. Then, ideas emerged where the school was construed as part of the constitution of society aimed at the fostering of citizens, where responsibility was given a quite different meaning. As argued in the curriculum of 1969:

The teaching of children and youths, provided for by society, aims to provide students with knowledge and to practise their skills, as well as to, in cooperation with their homes, promote children's and youth's development into harmonious, capable and responsible members of society. (Lgr 69, 1969, p. 10)

Responsibility is here connected to ideas about being a member of something larger than the self and the relation to a few others. As further developed in the curriculum:

The school is a part of society. If the school is to succeed in helping students into become good members of society, the school need to provide students with knowledge about society and strengthen their affinity to society. (Lgr 69, 1969, p. 11)

In relation to the curriculum of 2011, there is thus in 1969 a much stronger focus on the individual as part of society, a 'member of different communities'. In this context, affinity is a key idea.

The individual is a member of different communities. She is also a member of the national as well as the international community. If she is to find her place in life, she has to, during her time in school, get the opportunity to practise living and acting in a community with others, and to prepare for her role as an active citizen in the society of tomorrow. Such a society will to a greater extent than currently, demand cooperation and solidarity between people. (Lgr 69, 1969, p. 10)

Cooperation is here connected to a broader idea of society, as compared to the quite narrow definition used in the current curriculum of 2011, where cooperation first and foremost relates to the individual's social relations on the labour market. In the curriculum of 1969, solidarity is a key concept signifying the individual's social responsibility towards other people, and society in general. Thus, responsibility is not something the individual only directs towards the self, but also towards others, that is towards the broader societal community.

Life in a democratic society has to be based on free and independent people. Freedom and independence are not ends in themselves, but they need to be the basis for cooperation. The school should thus provide a basis and develop skills that can support and strengthen the principals of democracy in terms of tolerance, cooperation and equality among people. To induce respect for truth, for the selfworth of humans, the inviolability of human life, and thus the right for personal integrity, is a key task. It is important that students become helpful towards, and in cooperation with, all humans. (Lgr 69, 1969, p. 14-15)

The strong focus on the school's task of fostering the individual as part of and as respecting the collective is also clearly expressed in the curriculum of 1980. In a longer paragraph where the task of the school is discussed in terms of fostering students according to 'democratic principles', it is stated that:

The school should foster. This means that the school actively and consciously should affect and stimulate children and youths into wanting to adapt to the basic 
democratic values and turn these values into action in everyday life. The school thus needs to develop such characteristics among the student that can bear and strengthen democratic principles about tolerance, cooperation and equality among humans. To induce respect for truth, for the self-worth of humans, the inviolability of human life and thus the right for personal integrity is a key task for the school. Among other things, this means that the school should foster in students an understanding that no human should be oppressed, and no one with problems and difficulties should be left to their fate. Each and every person has a responsibility to try and lessen other people's pain, suffering and degradation. Life in democratic society has to be shaped by free and independent individuals. [...] This means that school should strive to give students the abilities to put themselves in others' shoes, and understand their situation and act according to their best interests. (Lgr 80, 1980, p. 18-19).

As in the curriculum of 1969, there is a strong emphasis on the responsibility of the individual towards the collective, and particularly towards those individuals who are weak: 'The strong persons' responsibility and care for the weaker has to be emphasized' (Lgr 80, 1980, p. 20).

In the curriculum of 1994, there is a different conceptualisation of responsibility. The individual is still related to a broader context, wherein the responsibility of the individual is emphasized. However, there is now a much stronger emphasis on values and the reproduction of values, framed in a wider discourse on 'Christianity and Western humanism'.

The school has an important task concerning the mediation and anchoring of the basic values on which our society is built. The inviolability of human life, the freedom and the integrity of the individual, all humans' equal value, equality between women and men, as well as solidarity with the weak and the exposed, are the values that the school should mould and mediate. According to the ethics of Christianity and Western humanism this is done through the fostering of a sense of justice, generosity, tolerance and responsibility. (Lpo 94, 1994, p. 1).

Even though the concept of solidarity is still used in the curriculum of 1994, the relation between self and others, between self and a broader societal community, becomes one in which there is someone who should show generosity towards others. This is quite a different relation as compared to previous curriculums, where the relation between the individual, society and the collective is much more constructed as a relationship based on the political principle of equality rather than on ethical principles of the individual's sense of 'justice, generosity, tolerance and responsibility'. Here, responsibility is primarily connected to the individual and the freedom of the individual.

The task of school is to let each student find her uniqueness and thus be able to participate in social life by giving one's best by means of responsible freedom (Lpo 94, 1994, p. 1).

In the curriculum of 1994, responsibility is repeatedly constructed in relation to freedom, characterising a certain kind of responsible subject, guided by a sense of 'responsible freedom'. The responsibility of the individual is further emphasized by an explicit focus on the active participation of the students and particularly on the freedom of choice as democratic core values and as means of developing an ability to take responsibility among the students.

It's not sufficient to mediate knowledge about basic democratic values. Teaching should also be carried out through the use of democratic working forms, and to 
prepare students for active participation in society. The working forms should develop students' ability to take personal responsibility. By participating in the planning and evaluation of daily teaching activities, and by choosing courses, subjects, themes and activities, students can develop their abilities to influence and to take responsibility (Lpo 94, 1994, p. 2).

The responsibility of the individual towards the collective is not very visible in the curriculum of 1994. Rather, such responsibility is primarily formulated in terms of values, understanding, identity and cultural heritage.

Internationalisation of society, and the growing mobility across borders puts high demands on people's abilities to live with and realize the values on which cultural plurality is based. Consciousness about one's own cultural heritage as well as involvement in the common cultural heritage, provides a safe identity that is important to develop in combination with the ability to put oneself into others' shoes and understand their conditions and values. The school is a social and cultural meeting place that has both an opportunity and responsibility to strengthen this ability among all who are working there. (Lpo 94, 1994, p. 1)

Here, the individual is constructed as belonging to certain communities sharing particular values. Within the framework of such a construction, responsibility is conceptualised in terms of an individual responsibility for developing one's consciousness about and sense of understanding for one's own 'cultural heritage', that is for one's self, as a means of understanding others. Thus, such a conception of responsibility differs from the one found in previous curriculums, by shifting the focus from the collective to the individual, where the individual is conceptualised as part of certain communities of values, rather than as part of certain societal collectives, sharing common interests as members of these.

We have in this section illustrated how there has been a shift in discourse regarding the relationship construed between citizens in terms of responsibility. In the curriculum from 1969 as well as 1980, there was a citizen shaped aimed at solidarity with others and especially with the weak. In the curriculums from 1994 and 2011 another citizen is shaped, one who is responsible for themselves emerge. Such a shift is further illustrated if we focus on another key event that lie behind the historical beginnings of the discourse today, namely problem-solving.

\section{The ability and will to solve problems}

In the current curriculum, problem-solving is seen as a key skill students need to develop in order to become desirable future citizens. 'The school should encourage students' creativity, curiosity and self-confidence, and willingness to test ideas and solve problems... In this way, the school should help the students to develop an approach promoting entrepreneurship' (Lgr 2011, p. 6). Problem-solving thus becomes a skill that students should develop in order to become entrepreneurial, and thus citizens who can face the changing future. Such a way of inserting problem-solving in the discourse today is quite different compared to the way problem-solving is construed in the curriculum of 1969. Here, the solving of problems is construed as a means for learning rather than a goal in itself.

As a common rule, learning needs to be based on motivation in order for there to be lasting results. Work in school has to address the students' interests and needs. Students should be faced with problems and put in situations where there is a requirement for certain knowledge and skills in order to find a solution. In educational psychology this is usually called the creation of motivation. ( $\operatorname{Lgr} 69$, 1969, p. 57) 
Here, problem-solving is construed as a method for teaching and learning, and not primarily as a skill developed in order for students to become citizens who can cope with a changing future. Rather than connecting such ideas with entrepreneurship, problem-solving connects with knowledge production within educational psychology. Thus, different concepts emerge, not least that of motivation. Motivation is key in order to shape students to become goal-oriented and law abiding citizens.

Central elements of the schools effort to promote the student's motivational development are the shaping of self-trust, initiative and his ability to thoroughly and with endurance work towards reaching defined goals as well as develop his will for good cooperation with others. The school should provide him with a good sense of those values and principles on which our justice system, in our democratic society, is based. He has to become fully aware of the meaning of concepts such as justice, honesty and tolerance, as well as aware of the consequences of breaking laws and regulations. (Lgr 69, 1969, p. 13)

Motivational work is closely connected to ideas of a rapidly changing society. So rather than speaking about problem-solving skills as entrepreneurial, problem-solving skills here connect up with individual motivation as a means to become active and take part in the development of society. In doing so, rapid changes can be faced and handled.

Society is in rapid change and the school has to arouse interest in active participation in the development of society. The school can't be isolated from society. School work thus has to be adapted not only to the development of the individual student but also to the development of society. School work has to be directed towards the future and prepare students to face changing conditions and new demands. In a changing society it's neither possible nor appropriate to, in detail, define content or working forms. The tasks of school thus have to continuously be re-evaluated. (Lgr 69, 1969, p. 11)

In the curriculum from 1980, problem-solving is construed as something that can only positively emerge if students learn to 'master basic concepts' and develop an 'understanding of overall contexts and relations'. Teaching needs to take this into account in order to avoid 'detrimental effects on their [students] self-trust and motivation' (Lgr 80, 1980, p. 16). Teaching should be designed based on students' own definitions of problems, and thus, the idea goes, students should become better at solving problems. As argued in the curriculum:

If it's possible to start school work with a certain problems defined by students themselves, there are good possibilities for the school to train them in problemsolving. Students should learn to realise the value of developing good knowledge as a means for continuous work, and they should also learn to select the information of importance for specific contexts, to draw logical conclusions, and to test the arguments of peers, and ultimately, propose a solution. (Lgr 80, 1980, p. 50)

With a focus on taking the starting point in problems defined by students, problem-solving is thus closely connected to ideas about motivation, ideas that are further connected to ideas about students' curiosity as a resource for learning, illustrated in the following quotation.

The starting point for working with different areas of knowledge should be students' views on reality. Teachers have to build their teaching based on students' 
curiosity, and to allow them to define and find solutions to their own questions, and to pose problems that encourage their curiosity. (Lgr 80, 1980, p. 50)

In the curriculum from 1994, problem-solving skills are construed as necessary in order to meet the rapidly changing future. With a sound basis in terms of knowledge needed by each citizen, it is possible to orient oneself in a 'complex reality'. By learning specific methods, students should gain the skill to continuously acquire the knowledge needed to face the future.

The school has a mission to transfer basic values and to promote students' learning in order to prepare them to live and operate in society. The school should promote more durable knowledge that constitutes the common frame of reference needed for all members of society. Students should orient themselves in a complex reality with a substantial flow of information and rapid speed of change. Study skills and methods useful in order to acquire and use new knowledge are thus important. It's also necessary that students develop their ability to critically examine facts and conditions, and to realise the consequences of certain alternatives [...] An important task for school is to provide overview and context. Students should have the possibilities to use their initiative and take responsibility. They should be provided with conditions that make it possible for them to develop their ability to work independently and to solve problems. (Lpo 94, 1994, p. 6-7)

The student emerging here is thus one who 'develops the ability to work independently and to solve problems'. In order to become such a citizen, students need to develop skills that make it possible for them to continuously acquire new knowledge during life. With such skills, it will become possible for students to constantly define and find solutions to problems and thus adapt to the changing future. More specifically, what is needed is to shape a constant will and desire for learning among students, which is clearly illustrated in the following quotation.

In school, students should be respected for their personality and their work. The school should strive to be a living social community providing security and a will and desire for learning. (Lpo 94, 1994, p. 7)

In this section, we have illustrated how developing problem-solving skills, which today is a key idea in the discourse on entrepreneurship and entrepreneurship education, is not something new. However, the meaning of this idea has changed over time. Today, problem-solving is construed as needed in order to face the changing future. Such skills are among those skills needed for students to constantly learn, and hopefully, they provide the basis for the development of a constant desire and will for learning. Going back to the curriculum from 1969 and 1980, problem-solving was instead connected to ideas about motivation, and as a way to help students learn in school, and thus shaped citizens who could be active in the development of society.

\section{Conclusion}

In this article, our aim has been to contribute to debates on entrepreneurship education in general, as well as in Sweden in particular. Our focus has been directed at how the discourse of entrepreneurship education is shaped in the school curriculum today, and how such discourse has come to emerge. By focusing on two key organising events that lie behind the historical beginnings of the discourse today, those of responsibility and problem-solving, and by tracing these back in time, we have been able to illustrate how the discourse on entrepreneurship education today shapes a specific kind of citizen, one who is responsible for themselves and their life trajectories, and who has developed a constant will and desire for learning, thus being able to adapt to the constant changing future. Entrepreneurial skills are thus tied to life in general, rather than only to 
the idea of skills needed in order to get a job or to start a business. Life itself has become entrepreneurial. Such a citizen is distinctly different from the one emerging in the curriculum from 1969 and 1980. In 1969 and 1980, a citizen that shows solidarity with others, and especially the weak, and who develops problem-solving skills in order to actively engage in the development of society, emerges. Problem-solving skills connect with ideas about motivation for learning in school, as well as skills needed in order to contribute to and take responsibility for the development of society.

The shaping of the entrepreneurial citizen today, through entrepreneurship education, is thus neither neutral nor apolitical. Ideas tied to a discourse on entrepreneurship education, such as responsibility and problem-solving might seem positive and productive in the shaping of students who can handle the future. However, as we have illustrated, these seemingly unproblematic ideas gain specific meaning by the ways they are connected up in the discourse on entrepreneurship education, and thus they do something in terms of shaping subjectivity. As we have illustrated, the entrepreneurial citizen emerges as a person who should focus on the self as a way to face the constantly changing future, rather than as someone who should take responsibility for themselves and others in the name of solidarity. What emerges is, what in the Foucault-inspired literature has been called an 'entrepreneurial self' (see e.g. Foucault, 2007; Simons and Masschelein, 2008; Rose, 1999). Such self is one who should capitalize on their leaning in order to be responsible, creative, problem-solvers. Through such means, citizens are expected to become employable, and thus productive to society (Fejes, 2010). The shaping of an entrepreneurial citizen is thus political, and needs to be problematized in relation to wider trends in society.

Our analysis can be related to the wider trends in education policy-making, where neoliberal rationalities have become more central. Specifically, scholars have illustrated how entrepreneurship education has become central in the practice of education in many locations, such as Finland (Komulainen, et al. 2009; Brunila, 2012), the UK (Jones \& Iredale, 2010; Matlay \& Carey, 2007), Ireland (Birdthistle, et al. 2007) and the US (Solomon, 2007). In Sweden, neoliberal rationalities emerged several decades ago, but became a predominant way to think about education in the early 1990s, when several market reforms took place in Swedish education (see e.g. Lundahl, et al. 2014). With neoliberalism, several shifts have taken place. One such shift is the one illustrated in our analysis, that is the shift of responsibility from the self and others in order to contribute to the development of society, to the responsibility for the self in order to adapt to the constantly changing future. In the literature this has been called the responsibilization of the citizen, where freedom becomes both the prerequisite and effect of governing (Rose, 1999; Fejes \& Dahlstedt, 2013). Students should be instilled with a desire and will to learn, and by taking such a position, they become learning subjects, in other words students are positioned as free to become learning subjects, and when they have become such subjects, they are 'free'. Another change that has taken place during the last few decades is the shifting focus in education policy, from an understanding of education as a common good, to an understanding of education as a private good (Englund, 1996), which goes hand in hand with the increasing focus on the individual's adaptation to the demands and expectations of the market (Beach \& Dovemark, 2016; Fejes, 2010).

What is striking is that the changes above illustrated have, in terms of the inclusion of entrepreneurship in the curriculum, emerged without political controversy. Rather, the inclusion has been taken for granted as something good, unproblematic and neutral. Thus, the citizen produced inside and outside of education appears as a seemingly neutral subject. This is in itself highly problematic, as entrepreneurship education has indeed effects in terms of shaping specific kinds of citizens as well as shaping new relations between citizens, and between citizens and the state. These changes of education policy are somehow symptomatic of the state of education policy today, as well as welfare policy more generally, in Sweden and in several other countries across the globe, where market-oriented reforms in education and welfare more broadly 
are increasingly normalized and appear as the result of or a response to a seemingly natural development. Thus, crucial political changes in our times become de-politicized (Zizek, 1999; Harling et al. 2015). This is a serious challenge facing critical education research, and it highlights the need for problematizing approaches challenging the seemingly natural in the contemporary time. Thus, a space for critical debate might emerge (Foucault, 1983, 1991).

\section{References}

Beach, D., \& Dovemark, M. (2016). From learning to labour to learning for precarity. Ethnography and Education, 11(2), 174-188.

Bengtsson, A. (2014). Enterprising career education. International Journal of Lifelong Education, 33(3), 362-375.

Berglund, K., \& Holmgren, C. (2007). Entreprenörskap och skolan. Stockholm: Forum för småföretagsforskning.

Birdthistle, N., Hynes, B., \& Fleming, P. (2007). Enterprise education programmes in secondary schools in Ireland. Education + Training, 49(4), 265-276.

Brunila, K. (2011). The projectisation, marketization and therapisation of education. European Educational Research Journal, 11(3), 421-432.

Brunila, K. (2012). A diminished self. European Educational Research Journal, 11(4), 477-486.

Dahlstedt, M., \& Hertzberg, F. (2012). Schooling entrepreneurs. Journal of Pedagogy, 3(2), 242-262.

Dahlstedt, M., \& Trumberg, A. (2017). Towards a new education regime. In A. Ålund, et al. (Eds.) Reimagineering the nation. Peter Lang: Frankfurt am Main.

Ds 1997: 3. I entreprenörskapets tecken. Stockholm: Fritzes.

Englund, T. (ed.) (1996). Utbildningspolitiskt systemskifte?. Stockholm: HLS.

European Union (2006). Key competences for lifelong learning. Official Journal of the European

Union.

Fejes, A. (2010). Discourses on employability. Studies in Continuing Education, 32(2), 89-102.

Fejes, A., \& Dahlstedt, M. (2013) The confessing society. London: Routledge.

Foucault, M. (1983). On the genealogy of ethics. In H.L. Dreyfus \& P. Rabinow (Eds.) Michel

Foucault (pp. 229-253) Chicago: The University of Chicago Press.

Foucault, M. (1991). Questions of method. In G. Burchell, et al. (Eds.) The Foucault effect (pp. 73-

86). Chicago: The University of Chicago Press.

Foucault, M. (1998). The will to knowledge. London: Penguin Books.

Foucault, M. (2007). Security, territory, population. Houndmills: Palgrave MacMillan.

The Government Offices (2009). Strategi för entreprenörskap inom utbildningsområdet. Stockholm: The Government Offices.

Harling, M., et al. (2015). Pedagogik och postpolitik. In S. Lindblad, \& L. Lundahl (Eds.)

Utbildning, makt och politik (pp. 195-217). Lund: Studentlitteratur.

Holmgren, C. (2012) Translating entrepreneurship into the education setting. In K. Berglund, et al. (Eds.) Societal entrepreneurship (pp. 214-327). Cheltenham: Edward Elgar.

Hvinden, B., \& Johansson, H. (Eds.) (2007). Citizenship in Nordic welfare states. New York: Routledge.

Hytti, U., \& O'Gorman, C. (2004). What is 'enterprise education'?. Education + Training, 46(1), 1123.

Johannisson, B., Madsén, T., \& Wallentin, C. (2000). Aba! Företagsamt lärande. Stockholm: Utbildningsradion.

Jones, B. \& Iredale, N. (2010). Enterprise education as pedagogy. Education + Training, 50(1), 7-19 Komulainen, M., Korhonen, K., \& Räty, H. (2009). Risk taking abilities for everyone?. Gender and Education, 21(6), 631-649.

Komulainen, M., et al. (2011). Internal entrepreneurship. Journal for Critical Education Policy Studies, 9(1), 341-374. 
Korhonen, M., Komulainen, K., \& Räty, H. (2012). 'Not everyone is cut out to be the entrepreneur type'. Scandinavian Journal of Educational Research, 56(1), 1-19.

Leffler, E. (2006). Företagsamma elever. Umeå: Umeå University.

Leffler, E. (2009). The many faces of entrepreneurship. European Educational Research Journal, 8(1), 104-116.

Leffler, E., \& Svedberg, G. (2005). Enterprise learning. European Educational Research Journal, 4(3), 219-227.

Lgr 11. (2011). Läroplan för grundskolan, förskoleklassen och fritidshemmet. Stockholm: Skolverket.

Lgr 69. (1969). Läroplan för grundskolan. Stockholm: Skolöverstyrelsen.

Lgr 80. (1980). Läroplan för grundskolan. Stockholm: Skolöverstyrelsen.

Lpo 94. (1994). Läroplan för det obligatoriska skolväsendet, förskoleklassen och fritidshemmet. Stockholm:

Utbildningsdepartementet.

Lundahl, L., Erixon Arreman, I., Holm, A-S., \& Lundström, U. (2014). Gymnasieskolan som marknad. Umeå: Boréa.

Mahieu, R. (2006). Agents of change and policies of scale. Umeå: Umeå University.

Matlay, H. \& Carey, C. (2007) Entrepreneurship education in the UK, Journal of Small Business and Enterprise Development, 14, 2, 252-263.

Nyström, E. (1999). Entreprenörskap $i$ skolan. Stockholm: Stiftelsen Institutet för individanpassad skola.

Olson, M., \& Dahlstedt, M. (2014). Citizen formation for a new millennium in Sweden. Journal for

Critical Education Policy Studies, 12(2), 200-224.

Peters, M. (2001). Education, enterprise culture and the entrepreneurial self. Journal of Educational Enquiry, 2(2), 58-71.

Popkewitz, T. (1998). Struggling for the soul. New York: Teachers College Press.

Prop 1995/96: 222. Vissa åtgärder för att halvera arbetslösheten till àr 2000, ändrade anslag för budgetåret 1995/96, finansiering m.m.

Rose, N. (1999). The powers of freedom. Cambridge: Cambridge University Press.

Rothstein, B. (1998). Just institutions matter. Cambridge: Cambridge University Press.

Solomon, G. (2007). An examination of entrepreneurship education in the United States. Journal of Small Business and Enterprise Development, 14(2), 168-182.

Simons, M., \& Masschelein, J. (2008) The governmentalization of learning and the assemblage of a learning apparatus. Educational Theory, 58(4), 391-415.

Svedberg, G. (2007) Entreprenörskapets avtryck i klassrummets praxis. Umeå: Umeå University.

Taylor, C. (2010) The culture of confession from Augustine to Foucault. London: Routledge.

Wallin, J. (2014). Entreprenörskap $i$ skolan. Linköping: Linköping University.

Zizek, S. (1999). The ticklish subject. New York: Verso 